\title{
Neuman Systems Model in perioperative nursing care for adolescents with juvenile idiopathic scoliosis
}

\author{
Modelo de Neuman no cuidado de enfermagem perioperatório \\ de adolescente com escoliose idiopática juvenil \\ Modelo de Neuman en la atención de enfermería perioperatoria \\ para adolescentes con escoliosis idiopática juvenil
}

How to cite this article:

Pestana-Santos M, Santos MSR, Cabral IE, Sousa PC, Lomba MLLF. Neuman Systems Model in perioperative nursing care for adolescents with juvenile idiopathic scoliosis. Rev Esc Enferm USP. 2021;55:e03711. doi: https://doi.org/10.1590/S1980-220X2020001703711

\author{
Márcia Pestana-Santos ${ }^{1}$ \\ Margarida da Silva Reis Santos ${ }^{2}$ \\ Ivone Evangelista Cabral ${ }^{3}$ \\ Paula Cristina Sousa ${ }^{2}$ \\ Maria de Lurdes Lopes de Freitas \\ Lomba $^{4}$ \\ 1 Universidade do Porto, Instituto de Ciências \\ Biomédicas Abel Salazar, Porto, Portugal. \\ 2 Escola Superior de Enfermagem \\ do Porto, Porto, Portugal. \\ 3 Universidade do Estado do Rio de \\ Janeiro, Faculdade de Enfermagem, \\ Rio de Janeiro, RJ, Brazil. \\ 4 Escola Superior de Enfermagem \\ de Coimbra, Coimbra, Portugal.
}

\begin{abstract}
Objective: To implement the nursing process, based on the Neuman Systems Model and the International Classification of Nursing Practice terminology, in the care of an adolescent who underwent corrective surgery for juvenile idiopathic scoliosis. Method: This is a qualitative study of the type of single case, with triangulation of data collection techniques (formal clinical interview, notes in a field diary and medical record information), developed with a 17-year-old adolescent and indication for corrective surgery. The empirical materials generated with the interviews carried out at admission and at discharge, observation and medical record information were treated with categorical content analysis. Results: The categories of personal condition, anxiety, selfconcept, meaningful people, facilitating health resources, school, free time and leisure were recurrent. Diagnoses were defined with a focus on Anxiety, Knowledge on pain management (control) and Willingness (or readiness) to learn, associating them with the respective nursing interventions. Conclusion: The Model contributed to assess and recognize surgery stressors for the adolescent and to theoretically base the nursing process. The classification allowed systematizing nursing care records, elements of clinical practice, unifying vocabulary and codes.
\end{abstract}

\section{DESCRIPTORS}

Adolescent; Scoliosis; Anxiety; Perioperative Period; Classification; Standardized Nursing Terminology.
Corresponding author:

Ivone Evangelista Cabral

Rua Afonso Cavalcani, 275, Cidade Nova CEP 20211-110 - Rio de Janeiro, RJ, Brazil icabral44@hotmail.com
Received: 01/21/2020

Approved: 09/23/2020 


\section{INTRODUCTION}

Among the problems with indication for surgical correction in adolescence, scoliosis has a global prevalence that varies between $0.5 \%$ and $5.2 \%$, affecting three girls for each adolescent boy ${ }^{(1)}$. The aggressiveness of this surgical procedure, the risks of neurological injury or pain ${ }^{(2)}$ and the change in the adolescent's routine and expectations after surgery ${ }^{(3)}$ are factors that contribute to the increase in the level of anxiety ${ }^{(4)}$. There are real risks arising from neurological injury and that the result of surgery does not meet the adolescent's expectations. These complications can interfere with the continuity of their full development.

A preoperative assessment, from the perspective of holistic nursing, in addition to addressing the risk and developmental impairment variables, should be based on the assumptions of a nursing system model. The model should contribute for perioperative nurses to plan individualized care, avoiding being limited to routine and standardized care that depersonalize the nursing care provided to this adolescent ${ }^{(5)}$.

Most nursing models are generalizable structures that require adaptation to be implemented with specific human groups in singular situations, such as perioperative care for adolescents. Nurses must meet adolescents' needs and their individuality in this context ${ }^{(6)}$. The Betty Neuman Systems Model (NSM) addresses two main components, stress and people's reaction to stress. Both conditions can affect adolescents undergoing corrective surgery for juvenile idiopathic scoliosis.

If, on the one hand, the use of a nursing system model justifies the nature of the care to be implemented by nurses ${ }^{(7)}$, on the other, for the structuring and evolution of nursing care, the use of nursing classification systems has become a key tool in the care process ${ }^{(8)}$. The evolution of nursing care and the standardization of procedures are all the more comprehensive and global the more they allow the tools used. In the absence of theories or models that support a nursing care approach to adolescents in perioperative situations, the Neuman Model was chosen to theoretically base the nursing process in the care of hospitalized adolescents with a rare and limiting condition of interactions with their peers.

The International Classification for Nursing Practice $\left(\mathrm{ICNP}^{\circledast}\right)$ was developed by the International Nurses Council (ICN) to allow the use of a scientific and unified language, common to worldwide nursing. $\mathrm{ICNP}^{\varpi}$ is based on the use of standardized terminology, organized by axes, which names, classifies, links and describes elements of nursing practice (diagnoses/results and nursing interventions $)^{(9-10)}$. The use of this classification leads to logical reasoning, clinical decision-making, facilitating systematic documentation of practice and communication between nursing professionals and other areas ${ }^{(9,11)}$.

Given the above, the question is: how to implement the nursing process in the perioperative care of an adolescent undergoing scoliosis correction surgery, based on NSM and $\mathrm{ICNP}^{\circledast}$ terminology?

This study aimed to implement the nursing process, based on NSM and ICNP ${ }^{\oplus}$ in the perioperative care of an adolescent who underwent corrective surgery for juvenile idiopathic scoliosis.

\section{METHOD}

\section{Betty Neuman System Model}

According to NSM, individuals are an open and dynamic system, with cycles of entry, process and exit, which feedback continuously and organically ${ }^{(12)}$. In concentric circles, the five variables, physiological, developmental, psychological, sociocultural and spiritual, are organized in lines to constitute the system. The flexible, normal, resistance lines and basic structure are part of the system ${ }^{(13)}$ (Figure 1).

According to the position that stressors occupy, the defense lines serve as protection or cushioning ${ }^{(14-15)}$. The resistance lines lie between the normal line of defense and the basic structure. Each is composed of internal and external resources that protect individuals' integrity ${ }^{(15)}$. When these lines are effective, stability is restored and symptoms resulting from exposure to stressors are reversed ${ }^{(15)}$. 


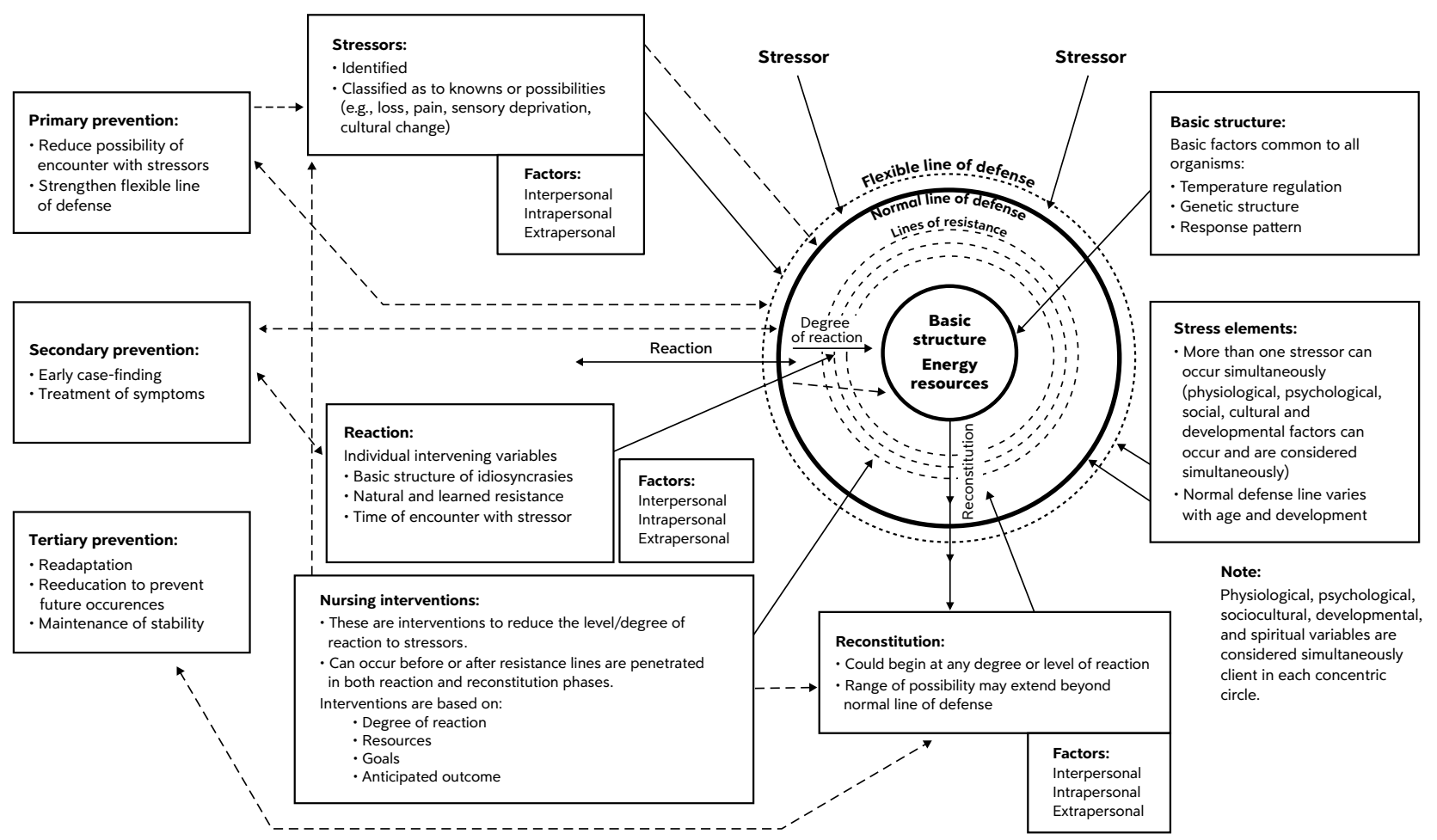

Figure 1 - Neuman Systems Model (original diagram) ${ }^{(13)}$

\section{TyPE OF STUDY}

A single case study was adopted, triangulating the data collection techniques (formal clinical interview, notes in the field diary and medical record information) in the development of a qualitative investigation ${ }^{(16)}$ of stressors associated with the perioperative of an adolescent, 17 years old, with juvenile idiopathic scoliosis, submitted to surgical intervention in a pediatric hospital in a city in Portugal. Scoliosis disturbs body self-image, in a period of life, adolescence, already marked by rapid and successive transformations in growth and development. Therefore, a single experience in the life of an adolescent-girl.

\section{CRITERIA FOR SELECTING THE PARTICIPANT IN THE SINGLE CASE}

An adolescent, living at that moment of data collection, having her first surgical experience to resolve a rare case juvenile idiopathic scoliosis, was selected. The surgical procedure should be the cause of severe functional limitation, high levels of perioperative anxiety and pain, which could influence the outcome of recovery and postoperative success.

\section{Data COlleCtion}

The data from the formal clinical interview were triangulated in two moments (at the hospital, upon admission and at the adolescent's home). The two moments of the interview took place in a calm environment. The adolescent chose that the interview would be conducted without the presence of any member of her family. The mother who accompanied her, both at the hospital and at home, was offered the possibility of watching the interview; however, out of respect for the adolescent's decision, she waited in a contiguous environment. The first interview lasted 24 minutes and the last, 29 minutes. In the first, data for the integrated evaluation in the preoperative nursing process was collected. Assessment took place in line with the five variables that make up the Model (physiological, developmental, psychological, sociocultural and spiritual). Between the two interviews, there were three formal contacts (before, on the day and after surgery). The adolescent's doubts and fears (stressors) and the need for additional explanations about the surgery were sought. In the last interview, the adolescent's perception of perioperative care and the influence on her well-being and recovery were addressed. The meetings were recorded in an observation diary. The interviews were recorded in audio and transcribed in verbatim to compose the textual corpus of analysis.

\section{DATA ANALYSIS AND TREATMENT}

As proposed by analysis of categorical content by Bardin $^{(17)}$, the statements in coding units were coded.Then, these units were indexed by common and singular meanings of cores of meanings to form the units of meanings (UM). The UM were reduced and grouped according to the categories and domains proposed in NSM (see Chart 1 in the results section of this article), relating these UM to ICNP nursing diagnoses ${ }^{(10)}$ (version 2019), $\mathrm{ICNP}^{\circledR}$ term codes used in the focuses, the diagnosis statements, the interventions, the diagnostic and assessment activities, and the outcomes.

\section{ETHICAL ASPECTS}

The research was approved by the institution's Health Sciences Ethics Committee, under reference CHUC-00119. In Portugal, only adolescents up to the age of 16 require 
informed and informed consent from the legal guardian. However, for this study, the adolescent and her mother signed consent terms, allowing their voluntary participation and recording of interviews. Both the adolescent and her mother were informed that they could give up participating in the study at any time, without harming the continuity of their care and health monitoring. Despite being a single case, all measures were taken to preserve participants' identity, anonymizing information, maintaining data secrecy and confidentiality.

\section{RESULTS}

\section{CASE REPORT}

A 17-year-old adolescent was followed up and prepared in consultation with an interdisciplinary health team, including an anesthesia nurse, throughout the perioperative period along the month preceding the surgery until the postoperative visit. She was admitted to the hospital, accompanied by her mother, two days before surgery. During nine days, she stopped attending school, stopped her sports activities and reduced contact with schoolmates.
She was discharged to the home seven days after the surgical procedure was performed.

\section{LINES OF DEFENSE AND STRESSORS}

Intrapersonal stressors correspond to the forces that the individual expresses in the care relationship. In the singular case of this adolescent, who underwent corrective surgery for idiopathic scoliosis, anxiety and pain were the stressors that stood out the most.

Among the interpersonal factors, that is, the forces that happen between one or more individuals, one considered the adolescent's relationship with the health team and with her mother and her expectation of relationships with friends during the recovery period. Extrapersonal factors are forces that occur outside the system and that act on individuals. School truancy for three weeks and interruption of physical activity and dance for a long period were the most influential external factors to the adolescent.

The UM were grouped into subcategories by stressors, categories, and domains (physiological, psychological, sociocultural) (Chart 1).

Chart 1 - Domains, categories, subcategories, and units of meaning - Coimbra, Portugal, 2019.

\begin{tabular}{|c|c|c|c|}
\hline Domain & Category & Subcategory & Units of meaning \\
\hline \multirow{3}{*}{$\begin{array}{l}\text { Physiological } \\
\text { variable }\end{array}$} & \multirow{3}{*}{$\begin{array}{l}\text { Personal } \\
\text { condition }\end{array}$} & Pain & $\begin{array}{l}\text { Everyone says that, after surgery, it hurts a lot. The } 2^{\text {nd }} \text { and } 3^{\text {rd }} \text { days were more complicated because of } \\
\text { the pain (long pause). More than back pain, it was stomachache. }\end{array}$ \\
\hline & & $\begin{array}{l}\text { Availability for } \\
\text { learning about } \\
\text { [pain] }\end{array}$ & $\begin{array}{l}\text { I want to learn how to use the [PCA - Patient Controlled Analgesia] machine that gives me } \\
\text { medication. On the eve of the surgery, they talked about physical therapy. I immediately wanted to } \\
\text { learn what breathing movements I would have to do (...) and what I would not have to do. }\end{array}$ \\
\hline & & Discomfort & $\begin{array}{l}\text { [in the preoperative period] When I was sitting, as I had a big rotation, I was never able to be well. I } \\
\text { didn't feel comfortable. [in the hospital] I was in no position to be, it was really hard. }\end{array}$ \\
\hline \multirow{4}{*}{$\begin{array}{l}\text { Psychological } \\
\text { variable }\end{array}$} & \multirow[b]{2}{*}{ Anxiety } & Impaired sleep & There were nights when I had trouble sleeping. I know there were risks (pause) [of neurological injury] \\
\hline & & Fear & $\begin{array}{l}\text { I was more nervous on the day of surgery. I remember starting to cry (pause) and feeling cold when I } \\
\text { left the ward to go to the [operating] room. }\end{array}$ \\
\hline & \multirow{2}{*}{$\begin{array}{l}\text { Self- } \\
\text { concept }\end{array}$} & Self-esteem & $\begin{array}{l}\text { I did not feel comfortable with my body (...) people noticed and commented (...) others look and } \\
\text { perceive (...) a deformity. Sometimes they speak without malice, but I feel bad about it. Some clothes } \\
\text { no longer felt very comfortable to wear because it was more noticeable. }\end{array}$ \\
\hline & & Self-image & $\begin{array}{l}\text { I'm very happy, for example, I bought bikinis and I was trying it on (pause), I liked seeing myself with } \\
\text { everyone (pause), I'm really happy (smiles). }\end{array}$ \\
\hline \multirow{6}{*}{$\begin{array}{l}\text { Sociocultural } \\
\text { variable }\end{array}$} & & Mother & $\begin{array}{l}\text { I know that before surgery my mother was more worried than me. I was with my mother. I knew I } \\
\text { was fine. My mother helped me with everything, in the hospital and now at home. }\end{array}$ \\
\hline & $\begin{array}{l}\text { Meaningful } \\
\text { people }\end{array}$ & Friends & $\begin{array}{l}\text { My friends visited me at the hospital. One day they went to visit me before going out for the night (...). } \\
\text { They went to show me how cute they were and that was important to me. } \\
\text { There were people [friends] who did not come to visit me at the hospital and I felt upset, really sad. } \\
\text { [cries when remembering] My friends help me a lot, because they carried my backpack and are } \\
\text { always careful. [friends] They ask if I'm fine. } \\
\text { I am still upset with the friends who did not visit me (pause) because, before surgery, they were } \\
\text { always saying that they would go there but that never happened [with watery eyes]. }\end{array}$ \\
\hline & \multirow{2}{*}{$\begin{array}{l}\text { Facilitating } \\
\text { health } \\
\text { resources }\end{array}$} & $\begin{array}{l}\text { Pre-operative } \\
\text { visit }\end{array}$ & $\begin{array}{l}\text { Knowing the whole team made me less worried or reticent about the surgery. It was important to be } \\
\text { able to meet everyone before surgery. }\end{array}$ \\
\hline & & Hospital & $\begin{array}{l}\text { The day before I visited the Intensive Care Unit and went to the Operating Room with nurses who } \\
\text { were going to welcome me. It was very important to visit the hospital before surgery. }\end{array}$ \\
\hline & \multicolumn{2}{|l|}{ School } & $\begin{array}{l}\text { I am in } 12^{\text {th }} \text { grade and will not be able to go to school for three weeks. I am afraid that I will not } \\
\text { be able to attend classes because I have to sit for a long time [classes are divided in periods of } 90 \\
\text { minutes each]. }\end{array}$ \\
\hline & \multicolumn{2}{|c|}{ Free time. Leisure } & $\begin{array}{l}\text { After surgery, I won't be able to play sports or dance for at least six months. As I will not return to } \\
\text { practice rhythmic gymnastics, after recovery, I will start ballroom dancing. }\end{array}$ \\
\hline
\end{tabular}

Legend: (...) - extracts from the original transcript irrelevant for analysis. 
Pain, Anxiety and risk of neurological injury were the most recurrent stressors. In the preoperative period, the adolescent's expectations regarding post-surgery can also function as a stressor, since the reality may differ from the expected.

Nurses, in nursing care planning and according to NSM, identify the nature of stressors, their real and potential effects, in partnership with the adolescent and her family, to establish a care plan adapted to the adolescent's needs. In this regard, a nursing care plan was developed using $\mathrm{ICNP}^{\otimes}$ terminology, with the presentation of the respective coding for focuses, diagnoses, interventions, diagnostic and assessment activities and for the nursing outcomes (Chart 2).

Chart 2 - Nursing diagnoses based on ICNP ${ }^{\circledR}$ terminology ${ }^{(10)}$ - Coimbra, Portugal, 2019.

\begin{tabular}{|c|c|c|c|c|c|c|c|}
\hline Focus & \begin{tabular}{|l} 
Diagnosis \\
activities
\end{tabular} & $\begin{array}{l}\text { Relevant data } \\
\text { for diagnosis }\end{array}$ & $\begin{array}{l}\text { Nursing } \\
\text { diagnosis }\end{array}$ & Goal & Result criteria & Nursing interventions & $\begin{array}{l}\text { Nursing } \\
\text { outcomes }\end{array}$ \\
\hline $\begin{array}{l}\text { Anxiety } \\
(10002429)\end{array}$ & $\begin{array}{l}\text { Assessing } \\
\text { Anxiety } \\
(10041745)\end{array}$ & $\begin{array}{l}\text { - Difficulty } \\
\text { sleeping in the } \\
\text { period prior to } \\
\text { surgery. } \\
\text { - On } \\
\text { observation, } \\
\text { she seems } \\
\text { concerned with } \\
\text { the surgery, } \\
\text { peripheral } \\
\text { tremor, } \\
\text { restlessness. } \\
\text { - She cried on } \\
\text { the surgery day. }\end{array}$ & $\begin{array}{l}\text { Anxiety } \\
(10000477)\end{array}$ & $\begin{array}{l}\text { Reduce the } \\
\text { adolescent's } \\
\text { anxiety in the } \\
\text { perioperative } \\
\text { period. }\end{array}$ & $\begin{array}{l}\text { That the } \\
\text { adolescent } \\
\text { develops } \\
\text { appropriate } \\
\text { strategies to } \\
\text { control anxiety. }\end{array}$ & $\begin{array}{l}\text { - Establishing Trust (10024396) } \\
\text { Promoting Positive } \\
\text { Psychological Status (10032505) } \\
\text { - Assisting (10002850) in Self- } \\
\text { Control (10046837) and Anxiety } \\
\text { (10000477) } \\
\text { - Guiding (10008592) in } \\
\text { the Relaxation Technique } \\
\text { (10016700) } \\
\text { - Implementing Comfort Care } \\
\text { (10039705) } \\
\text { - Promoting Family Support } \\
\text { (10036078) }\end{array}$ & $\begin{array}{l}\text { Reduced } \\
\text { Anxiety } \\
(10027858)\end{array}$ \\
\hline $\begin{array}{l}\text { Knowledge } \\
\text { Of Pain } \\
\text { Management } \\
(10034259)\end{array}$ & $\begin{array}{l}\text { Assessing } \\
\text { Knowledge } \\
\text { Of Pain } \\
\text { Management } \\
\text { (10039041) }\end{array}$ & $\begin{array}{l}\text { She does not } \\
\text { know the } \\
\text { pharmacological } \\
\text { and non- } \\
\text { pharmacological } \\
\text { strategies for } \\
\text { postoperative } \\
\text { pain relief. }\end{array}$ & $\begin{array}{l}\text { Knowledge } \\
\text { Of Pain } \\
\text { Management } \\
\text { (10033750) } \\
\text { Impaired } \\
\text { (10012938) }\end{array}$ & $\begin{array}{l}\text { Improve the } \\
\text { adolescent's } \\
\text { knowledge } \\
\text { on pain } \\
\text { management. }\end{array}$ & \begin{tabular}{|l|} 
That the \\
adolescent \\
improves \\
knowledge about \\
pharmacological \\
and non- \\
pharmacological \\
strategies for pain \\
management in \\
the postoperative \\
period.
\end{tabular} & $\begin{array}{l}\text { - Teaching About Managing } \\
\text { Pain (10019489) } \\
\text { - Teaching About Pain } \\
\text { (10039115) [non- } \\
\text { pharmacological strategies] } \\
\text { - Teaching About Medication } \\
\text { (10019470) } \\
\text { - Guiding How To Use } \\
\text { Patient Controlled Analgesia } \\
\text { (10039073) [How to use PCA] } \\
\text { - Collaborating on Pain } \\
\text { Management Plan (10039831) } \\
\text { [pharmacological and non- } \\
\text { pharmacological strategies] }\end{array}$ & $\begin{array}{l}\text { Knowledge } \\
\text { Of Pain } \\
\text { Management } \\
(10033750) \\
\text { Effective } \\
(10014956)\end{array}$ \\
\hline $\begin{array}{l}\text { Readiness } \\
\text { To Learn } \\
\text { (10016422) } \\
\text { about Pain } \\
\text { (10023130) }\end{array}$ & $\begin{array}{l}\text { Assessing } \\
\text { Readiness } \\
\text { to Learn } \\
(10002781)\end{array}$ & $\begin{array}{l}\text { She questions } \\
\text { how pain } \\
\text { control will } \\
\text { be in the } \\
\text { postoperative } \\
\text { period. } \\
\text { Shows interest in } \\
\text { learning about } \\
\text { pain control. }\end{array}$ & $\begin{array}{l}\text { Readiness } \\
\text { To Learn } \\
\text { (10016422) } \\
\text { [about pain] } \\
\text { Effective } \\
(10014956)\end{array}$ & & & & \\
\hline
\end{tabular}

Figure 2, based on NSM and adapted to the case under study, represents the stressor elements, stressor factors, the three levels of prevention, nursing interventions using
$\mathrm{ICNP}^{\circledR}$ terminology as well as actions for reconstitution. The adolescent is represented at the center protected by the lines of resistance, normal defense and flexible defense. 


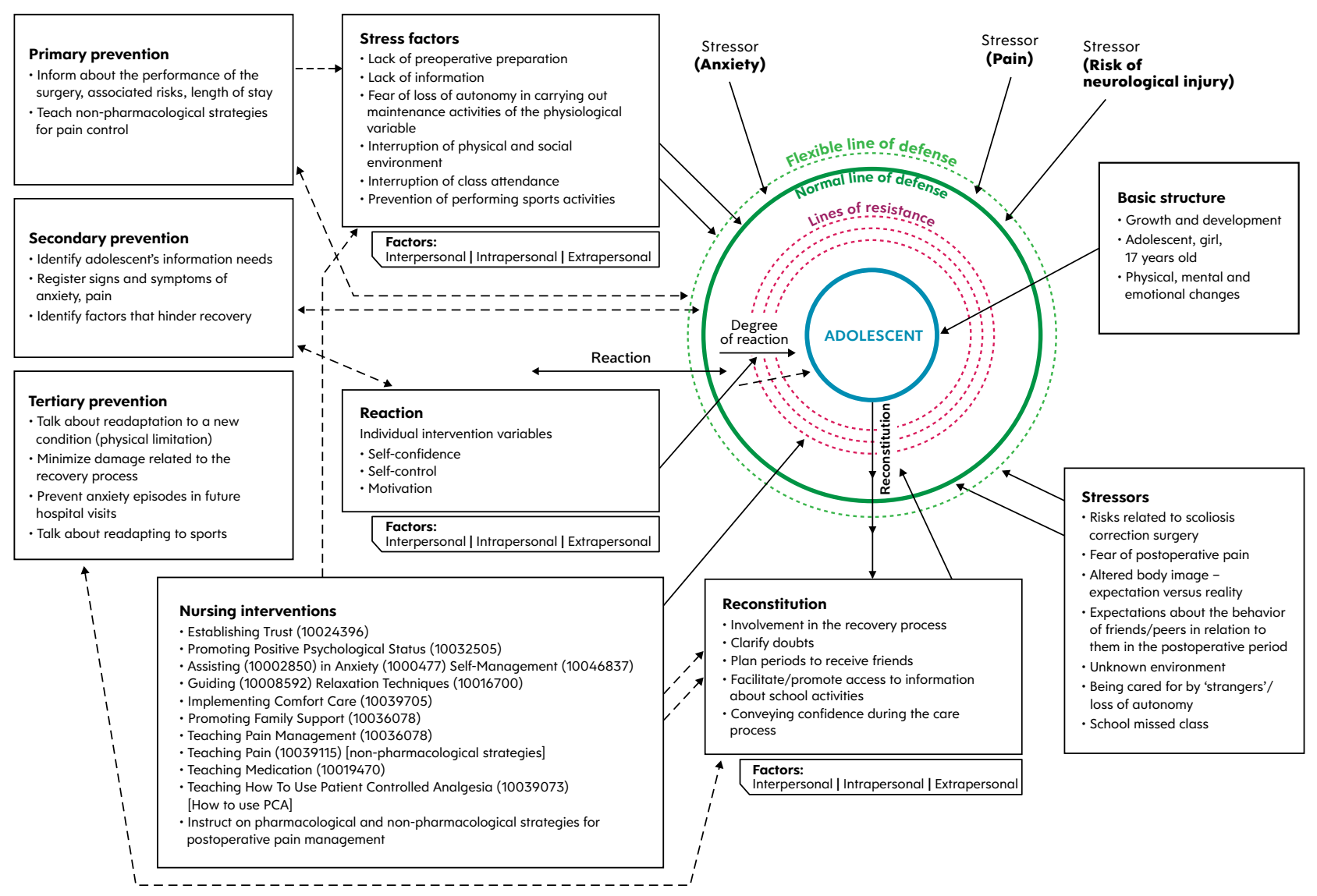

Figure 2 - Adapted Neuman Systems Model. Prepared by the authors.

\section{DISCUSSION}

In scoliosis correction surgery, adolescents have their flexible line of defense closer to the normal line, given the contact with multiple stressors inherent to this procedure. The normal line of defense is characterized by habitual well-being, i.e., the stability that results from adapting over time to various stressors with which the adolescent deals. The normal line of defense is dynamic, providing system stability and integrity of the basic structure, when exposed to stressors with which individuals have already had contact ${ }^{(15)}$.

The nursing interventions defined for each of the diagnoses are intended to strengthen lines of defense, reduce the impact of a stressor and promote the best possible level of well-being for the adolescent after reconstitution or recovery. Primary interventions bring together a set of actions that promote well-being, favoring the reduction of risk factors, avoiding their occurrence and contact with the lines of defense. As primary interventions in the perioperative period, it was defined to provide information related to the performance of surgery on associated risks and hospitalization period and to teach about non-pharmacological strategies for pain control.

These actions strengthen the flexible line of defense and simultaneously protect it ${ }^{(15)}$. Secondary prevention, on the other hand, consists of a set of interventions performed after contact and adolescents' reactions to stressors. As secondary interventions in the perioperative period, to 'detect' the information needs of the adolescent, the signs and symptoms of anxiety, the presence of pain and the factors that hinder recovery were defined. Secondary interventions aimed at reducing symptoms, reducing reactivity to stressors, using resistance lines and strengthening them. In order to achieve nursing outcomes, it is necessary to mobilize internal and external resources to conserve energy and achieve the possible level of stability ${ }^{(14)}$.

As tertiary interventions in the perioperative period, readaptation to the new condition was identified due to the physical limitation caused by the surgery, minimizing damage related to the recovery process, preventing episodes of anxiety in future visits to the hospital and working with the adolescent to readapt sports practices. Tertiary prevention begins after reconstitution, with the development of interventions aimed at readaptation, education for the prevention of new occurrences and the maintenance of the adolescent' stability and well-being, conserving energy and promoting their strengths, returning to primary prevention ${ }^{(15)}$. The assessment of the defined goals and the success of the interventions determine the nursing outcomes ${ }^{(13)}$.

Using ICNP ${ }^{\circledast}$ terminology ${ }^{(10)}$ to develop a nursing process unifies language, in order to identify, explain and assess the elements of a clinical practice case, enabling the improvement of actions through a more reflective, effective and efficient performance ${ }^{(8)}$. Using this universal language, recognized by the ICN, facilitates the communicative and relational process between nurses and other members of the multidisciplinary health team, giving greater recognition and visibility to the 
profession $^{(8)}$, which is particularly important in the pediatric clinical context.

NSM, in the development of a nursing process, helped to develop an adequate assessment and systematization of the care to be implemented, taking into account the five variables that constitute the basic structure of the adolescent. In the perioperative care approach, stressors and factors with the potential to negatively influence the adolescent's recovery were identified. Stressors that would compromise the result of the procedure or interfere with the expected course of the adolescent's development stood out.

Complications related to anxiety, pain and the risk of neurological injury were the most recurrent, being also reported in other studies with adolescents in perioperative situation $^{(4,18,19)}$. As stressors, preoperative preparation, information made available, fear of loss of autonomy, withdrawal from their environment, interruption in the frequency of teaching activities, as well as impediment to perform sports activities were identified. These factors coincide with those reported by other adolescents when they described the surgical experience for scoliosis correction ${ }^{(18)}$.

As stressors, risks related to scoliosis correction surgery, fear of postoperative pain, changes in body image (expectation versus reality), expectations about the behavior of friends/peers in relation to them in the postoperative period, the unknown environment, being cared for by strangers, loss of autonomy and school truancy stand out. The more complex the surgical problem and the consequent recovery, the more evident the elements and factors that cause stress ${ }^{(4)}$. Thus, when adolescents are confronted with information about the risks and perspective of postoperative pain, they may be concerned and express anxiety, with significant distress ${ }^{(18)}$.

Thus, the focuses Anxiety and Knowledge On Pain coincide with those of other studies that also report a correlation between preoperative anxiety, pain, sleep disorders and maladaptive behaviors in adolescents ${ }^{(20,21)}$. Prior contact with information related to surgery lacks proper implementation of anxiety and pain prevention interventions so that adolescents can be better prepared.

For the $\mathrm{ICN}^{(10)}$, anxiety is characterized as a negative emotion, with feelings of threat, danger or anguish. Knowledge corresponds to specific content of thought, based on acquired wisdom, or on information or skills learned, knowledge and recognition of information ${ }^{(10)}$. Defines willingness (or readiness) to learn how to be ready or available to act or move forward ${ }^{(10)}$. Willingness to learn is described "as the moment when the apprentice shows interest in learning the information necessary to maintain excellent health or to become more skilled in some task"(22). Readiness happens when apprentices are receptive, willing and able to participate in the educational process for the event ${ }^{(22)}$.

According to what was proposed by Neuman, implementing primary, secondary and tertiary interventions aims to protect the basic structure of the adolescent by strengthening the lines of defense and lines of resistance ${ }^{(15)}$. Interventions such as teaching about pain management, managing anxiety or establishing trust contribute to mitigate the impact of the perioperative environment on individuals, improving the experience as well as the perception of well-being throughout the perioperative period ${ }^{(23)}$.

The theoretical, philosophical and conceptual framework of the model allowed to expand the view of nursing directed to holism and well-being ${ }^{(13)}$. Nurses play an important role in perioperative care for adolescents, when interpreting, assessing and promoting relief from pain and anxiety. Such care includes preparing for surgery, informing the adolescent and their family about what to expect, providing a calmer and safer environment and responding to the needs presented by them ${ }^{(18)}$.

\section{Study limitations}

Triangulation of techniques has the methodological potential to minimize bias with single case research (juvenile idiopathic scoliosis). The case of a single adolescent may limit the generalization of findings to other adolescents. It is suggested that more studies be carried out in perioperative contexts, such as case series or in a case study with more adolescents, using NSM and $\mathrm{ICNP}^{\oplus}$ terminology.

Another limitation was the inclusion of the family in the context of hebiatric care, as it would require modeling of nursing diagnoses that are not part of the single case study methodology centered on the adolescent in the study.

\section{IMPLICATIONS FOR PRACTICE}

The findings of this study can be applied to similar situations that are experienced by adolescent girls, once the meaning of anxiety and knowledge about pain control is understood as the most recurrent aspects in the perioperative experience. Implementing the model can allow the systematization and excellence of nursing care for adolescents in the perioperative period.

In future studies related to perioperative care in complex resolving surgical conditions, NSM variables can be explored, highlighting the parental role as part of the balance of the family system.

\section{CONCLUSION}

Identifying intra, inter, extrapersonal factors and stressors guided planning care according to the three levels of integrated prevention that the model proposes. Thus, the development of the care process for an adolescent with scoliosis obtained successful responses when reaching the nursing outcomes.

The model is applicable and appropriate to the context of perioperative care for adolescents, as the main focuses of nurses'attention led to the prescription of interventions that respond to the priority problems of adolescents in perioperative situations for surgical correction of scoliosis. 
Método: Estudo qualitativo do tipo de caso único, com triangulação de técnicas de coleta de dados (entrevista clínica formal, notas em diário de campo e informações de prontuário), desenvolvido com uma adolescente de 17 anos de idade e indicação de cirurgia corretiva. Os materiais empíricos gerados com as entrevistas realizadas na admissão e na alta, a observação e informações de prontuário foram tratados com a análise de conteúdo categorial. Resultados: Foram recorrentes as categorias condição pessoal, ansiedade, autoconceito, pessoas significativas, recursos de saúde facilitadores, escola, tempos livres e lazer. Definiram-se diagnósticos com foco nos problemas Ansiedade, Conhecimento sobre Manejo (controle) da Dor e Disposição (ou prontidão) para Aprender, associando-os às respectivas intervenções de enfermagem. Conclusão: O Modelo contribuiu para avaliar e reconhecer fatores estressores do evento cirúrgico na adolescente e fundamentar, teoricamente, o processo de enfermagem. A classificação permitiu a sistematização de registos dos cuidados de enfermagem, dos elementos da prática clínica, unificação de vocabulário e de códigos.

\section{DESCRITORES}

Adolescente; Escoliose; Ansiedade; Período Perioperatório; Classificação; Terminologia Padronizada em Enfermagem.

\section{RESUMEN}

Objetivo: Implementar el proceso de enfermería, basado en el Modelo de Sistemas Neuman y la terminología de la Clasificación Internacional de la Práctica de Enfermería, en el cuidado de un adolescente que fue sometido a cirugía correctiva por escoliosis idiopática juvenil. Método: Estudio cualitativo del tipo de caso único, con triangulación de técnicas de recolección de datos (entrevista clínica formal, anotaciones en diario de campo e información de historia clínica), desarrollado con una adolescente de 17 años e indicación de cirugía correctiva. Los materiales empíricos generados con las entrevistas realizadas al ingreso y al alta, la observación y la información de la historia clínica fueron tratados con el análisis de contenido categórico. Resultados: Las categorías de condición personal, ansiedad, autoconcepto, personas significativas, recursos facilitadores de salud, escuela, tiempo libre y ocio fueron recurrentes. Los diagnósticos se definieron con un enfoque en los problemas Ansiedad, Conocimiento sobre el Manejo del Dolor (control) y Voluntad (o disposición) para Aprender, asociándolos con las respectivas intervenciones de enfermería. Conclusión: El Modelo contribuyó a evaluar y reconocer los factores estresantes del evento quirúrgico en el adolescente y a fundamentar teóricamente el proceso de enfermería. La clasificación permitió la sistematización de registros de atención de enfermería, elementos de la práctica clínica, unificación de vocabulario y códigos.

\section{DESCRIPTORES}

Adolescente; Escoliosis; Ansiedad; Periodo Perioperatorio; Clasificación; Terminologia Normalizada de Enfermería.

\section{REFERENCES}

1. Choudhry MN, Ahmad Z, Verma R. Adolescent idiopathic scoliosis. Open Orthop J. 2016;10:143-54. doi: 10.2174/1874325001610010143

2. Chan P, Skaggs DL, Sanders AE, Villamor GA, Choi PD, Tolo VT, et al. Pain is the greatest preoperative concern for patients and parents before posterior spinal fusion for adolescent idiopathic scoliosis. Spine. 2017;42(21):E1245-50. doi: 10.1097/BRS.0000000000002147

3. Sieberg CB, Manganella J, Manalo G, Simons LE, Hresko MT. Predicting postsurgical satisfaction in adolescents with idiopathic scoliosis: the role of presurgical functioning and expectations. J. Pediatr Orthop. 2017;37(8):e548-51. doi: 10.1097/BPO.0000000000000778

4. Duramaz A, Yılmaz S, Ziroğlu N, Bursal Duramaz B, Kara T. The effect of deformity correction on psychiatric condition of the adolescent with adolescent idiopathic scoliosis. Eur Spine J. 2018;27(9):2233-40. doi: https://doi.org/10.1007/s00586-018-5639-4

5. Wellburn S, Van Schaik P, Bettany-Saltikov J. The information needs of adolescent idiopathic scoliosis patients and their parents in the UK: an online survey. Healthcare (Basel). 2019;7(2):78. doi: 10.3390/healthcare7020078

6. Shields L. Perioperative care of the child: a nursing manual. United Kingdon: Wiley-Blakwell; 2010.

7. Monahan JC. Using an age-specific nursing model to tailor care to the adolescent surgical patient. AORN J. 2014;99(6):733-49. doi: http:// dx.doi.org/10.1016/j.aorn.2013.10.025

8. Clares JWB, Fernandes BKC, Guedes MVC, Freitas MC. Specialized nursing terminology for the care of people with spinal cord injury. Rev Esc Enferm USP. 2019;53:e03445. doi: http://dx.doi.org/10.1590/S1980-220X2018014203445

9. Garcia TR. ICNP ®: a standardized terminology to describe professional nursing practice. Rev Esc Enferm USP. 2016;50(3):376-81. doi: http://dx.doi.org/10.1590/S0080-623420160000400001

10. International Council of Nurses. ICNP Browser. [Internet]. Geneva: ICN; 2019 [cited 2019 Sept 19]. Available from: https://www.icn. ch/what-we-do/projects/ehealth/icnp-browser?fbclid=IwAR16oNBaXF-OZ38F8PGiTohRIccVWKSpjGjjP5x0OmJSmnbFuYkCMx7jAMc

11. Garcia TR, Nóbrega MML. A terminologia CIPE e a participação do Centro CIPe $®$ brasileiro em seu desenvolvimento e disseminação. Rev Bras Enferm. 2013;66(esp):142-50. doi: https://doi.org/10.1590/S0034-71672013000700018

12. Tomey, AM, Alligood, MR. Teóricas de Enfermagem e a sua obra: modelos e teorias de enfermagem. 5a ed. Loures: Lusociência; 2004.

13. Neuman B, Fawcett J. The Neuman Systems Model. 5th ed. Upper Saddle, NJ: Pearson; 2011.

14. Lawson T. Betty Neuman: systems model. In: Alligood MR, editor. Nursing theorists and their work. 9th ed. St. Louis: Elsevier; 2017. p. 281-302.

15. Lowry LW, Aylward PD. Betty Neuman's Systems Model. In: Smith MC, Parker ME, editors. Nursing theories and nursing practice. 4th ed. Philadelphia: F. A. Davis; 2015. p. 165-84.

16. Yin RK. Estudo de caso: planejamento e métodos. $4^{\mathrm{a}}$ ed. São Paulo: Artmed; 2010.

17. Bardin L. Análise de conteúdo. Lisboa: Edições 70; 2014.

18. Rullander AC, Lundström M, Lindkvist M, Hägglöf B, Lindh V. Stress symptoms among adolescents before and after scoliosis surgery: correlations with postoperative pain. J Clin Nurs. 2016;25(7-8):1086-94. doi: 10.1111/jocn.13137

19. Rullander A-C, Lundström $M$, Östlund $U$, Lindh V. adolescents' experiences of scoliosis surgery and the trajectory of self-reported pain: a mixed-methods study. Orthop Nurs. 2017;36(6):414-23. doi: 10.1097/NOR.0000000000000402 
20. Berger J, Wilson D, Potts L, Polivka B. Wacky Wednesday: use of distraction through humor to reduce preoperative anxiety in children and their parents. J Perianesth Nurs. 2014;29(4):285-91. doi: 10.1016/j.jopan.2013.06.003

21. Hilly J, Hörlin AL, Kinderf J, Ghez C, Menrath S, Delivet H, et al. Preoperative preparation workshop reduces postoperative maladaptive behavior in children. Paediatr Anaesth. 2015;25(10):990-8. doi: 10.1111/pan.12701

22. Bastable SB. O enfermeiro como educador: princípios de ensino-aprendizagem para a prática de enfermagem. $3^{\text {a }}$ ed. São Paulo: Artmed; 2010.

23. Pinto A, Faiz O, Davis R, Almoudaris A, Vincent C. Surgical complications and their impact on patients' psychosocial well-being: a systematic review and meta-analysis. BMJ Open. 2016;6(2):e007224. doi: http://dx.doi.org/10.1136/bmjopen-2014-007224 